Studia Judaica 19 (2016), nr 2 (38), s. 215-228

doi:10.4467/24500100STJ.16.010.6221

Judith Kalik

\title{
They Are Like Jews: \\ The Role of Jews in Inter-Confessional Christian Polemics in the Polish-Lithuanian Commonwealth
}

\begin{abstract}
Jews often appear in Christian polemical literature as clichéd archheretics in the context of inter-confessional Christian polemics, rather than for their own sake, in a polemic directed against Judaism itself. In the multiethnic and multi-religious Polish-Lithuanian Commonwealth political conflicts often took the form of religious polemics, and religion served as a central channel for expressing not only religious feelings but also national and political identity. The use of Jews in polemical literature was widespread and can be found in Orthodox polemics directed against the union with Rome, Uniates' defense of the union, Catholic-Protestant polemics in the context of the Counter-Reformation and in other contexts. This paper examines such use of Jews in inter-confessional Christian polemics in the Polish-Lithuanian Commonwealth.
\end{abstract}

Keywords: Union of Brześć, religious polemics, halakha, Sabbatian movement, Hussite movement, Arians, Kabbalah.

The perception of Jews in medieval and early modern Europe was determined by two major factors. On the one hand, the Jews were a minority living among the Christian majority, which was naturally preoccupied with its own issues and displayed little interest in Jewish culture and beliefs. On the other hand, Jews and Judaism had played a central role in Christianity's self-definition from the dawn of Christianity. Because of these contradictory factors, Jews appear in Christian polemical literature as clichéd arch-heretics in the context of inter-confessional Christian polemical literature, rather than for their own sake, in a polemic directed against Judaism itself. This use of the Jews as archetypical "heretics" was 
an integral part of the common Christian polemical tradition going back to the Fathers of the Church. ${ }^{1}$

In October 1596, a synod of the Polish-Lithuanian Orthodox Church at Brześć (Brest) declared the transfer of the Kievan Metropolitanate from the jurisdiction of the Patriarch of Constantinople to the Roman Catholic Pope. This act became known as the Union of Brześć. Simultaneously, a counter-synod, which was convened at the same location, condemned the Union with Rome and confirmed the loyalty of the Kievan Metropolitanate to Constantinople. Thus the Polish-Lithuanian Orthodox Church split in two, and a long struggle between supporters and opponents of the Union of Brześć commenced.

Because of the multi-ethnic and multi-religious composition of the Polish-Lithuanian Commonwealth, political conflicts often took the form of religious polemics. Religion served as a central channel for expressing not only religious feelings but also national and political identity. For this reason, polemical literature flourished in this country to an unusual degree, especially before and after the Union of Brześć.

In her book, Jews and Heretics in Catholic Poland, Magda Teter discussed the role of Jews in the Polish Catholic anti-Protestant polemic after the Reformation. ${ }^{2}$ However, it would seem that such use of Jews in polemical literature was widespread and can be found in, among others, Orthodox Church literature directed against Roman Catholics, Uniates, Protestants, and even Moslems. This paper examines such use of Jews in inter-confessional Christian polemics in the Polish-Lithuanian Commonwealth.

\section{Orthodox and Uniate Polemics on the Jewish halakha}

Various churches used Jews in differing ways in their polemical literature. Orthodox and Uniate polemists devoted their efforts to defending their Eastern ritual practices as opposed to the Roman Catholic Western rites. Their polemical arguments were partly derived from their interpretation of the Jewish halakha. Therefore, vivid discussions on Jewish halakhic matters were an integral part of this polemic. Especially important were

\footnotetext{
${ }^{1}$ On this subject see David Nirenberg, Anti-Judaism: The Western Tradition (New York, 2013).

${ }^{2}$ Magda Teter, Jews and Heretics in Catholic Poland: A Beleaguered Church in the PostReformation Era (Cambridge, 2006).
} 
two issues: the nature of Communion and the method for calculating the date of Easter. Differences between the Eastern and Western rites with regard to Communion go back to seeming contradiction in the New Testament itself: according to the Synoptic Gospels (Matthew, Luke, and Mark), the Last Supper took place on Passover Eve, but according to the Gospel of John, Jesus Christ was crucified on Passover Eve, symbolizing the Paschal lamb. Following the Synoptic Gospels, the Western Church believed that the bread proclaimed to be his body by Jesus during the Last Supper was in fact the Jewish matsah (unleavened bread or azyma in Greek). The Eastern Church followed John's version and claimed that the bread that was used on that occasion must be leavened bread (Hebrew hamets, Greek enzyma). Therefore, they concluded, leavened bread must be used for Communion also. Neither church was willing to admit to the existence of contradictions in the Holy Scripture. Already in the mid-eleventh century, on the eve of the Great Schism, Leo, Metropolitan of Ochrida (Ohrid), wrote a polemical tractate entitled "On the Unleavened Bread" (Peri tōn azymōn), where he claimed that the Last Supper of the Synoptic Gospels also took place before the Passover. He argued that this must be the case since, according to Luke 22.8, Jesus sent Peter and John to Jerusalem in advance, in order to purchase the Paschal lamb. Given that Mosaic Law (Exodus 12.3) states that this should be done on the tenth of Nissan, the Last Supper must have preceded Passover also. ${ }^{3}$ All polemists of the age of the Union of Brześć, both its opponents, such as Vasily of Ostróg, ${ }^{4}$ and its supporters repeat this argument, and there was even a special chapter of the Act of the Union dedicated to this matter. ${ }^{5}$ Of course, the eleventh-century clerics were unaware that the Mishnah defines this commandment as "Passover of Egypt" (Pesah Mitsrayim), as opposed to the "Passover of generations" (Pesah dorot) practiced in the Second Temple period (Psahim 9.5), since the very existence of Mishnah and Talmud was "discovered" in Western

3 “Послание Льва, митрополита русскаго," in Памятники древне-русскаго каноническаго права, vol. 2, part 1 (Петроград, 1920), 74-101 (Русская историческая библиотека, vol. 36).

${ }^{4}$ Василий Острожский, “О единой истинной православной вере и о святой соборной апостольской церкви, откуда начало приняла, и како повсюду распростреся,” in Памятники полемической литературы в Западной Руси, vol. 2 (Петербург, 1882), 633-638 (Русская историческая библиотека, издаваемая археографическою комиссиею, vol. 7).

5 “Уния греков с костелом римским," in Памятники полемической литературы в Западной Руси, vol. 2: 139-150. 
Europe only in the mid-twelfth century. It is significant that Orthodox and Uniate polemists were still ignorant about this "discovery" by the end of the sixteenth century. Roman Catholics found it necessary to stress in their response to this Orthodox argument that according to the Jewish tradition itself, the unleavened bread (matsah) is regarded as bread (lehem). ${ }^{6}$ The Roman Catholic view is beautifully expressed in the eighteenth-century sermons of Jan Stanisław Wujkowski, who explained to his audience that the Jews call "unleavened bread" not only matsah but also lehem oni (these Hebrew words are written in his text in Latin characters)_-"bread of poverty," since even the poor should be able to eat it on Passover Seder. Wujkowski also explains what an aphikoman is, relying on the Talmudic tractate of Psahim, on Maimonides, and on Abarbanel. ${ }^{7}$ The purpose of this learned discussion was to prove that the Last Supper had in fact been the Jewish Seder Pesah, and for this reason, Jesus had broken the bread, and did not cut it with a knife, as the Orthodox do with their leavened prosphora.

The second point of disagreement between the East and the West was the method of calculating the date of Easter. This controversy intensified with the Gregorian reform of 1582, when the date of vernal equinox was moved eleven days forward in the new calendar, which was adopted by the Roman Catholic Church, but rejected by the Orthodox. As a result, the Roman Catholic Easter sometimes coincided with the Jewish Passover, while the Orthodox Easter always lagged one week after it. Therefore, the Orthodox and Uniate polemists alike claimed that the Roman Catholic transgressed the ruling of the Nicean Council of 325, which prohibited celebrating Easter on the fourteenth of Nissan-the so-called Quartodeciman Heresy. The Roman Catholics, for their part, claimed that the Orthodox calculation of Easter is directly linked with the Jewish calendar, which was also prohibited by the same Council of Nicea. This last accusation is wrong, being based on an erroneous interpretation of Byzantine theologian John Zonaras' passage that "their [i.e. Jewish] nonfestal feast [i.e. Passover] must come first and then our Pascha should

${ }^{6}$ On the Catholic polemic see Judith Kalik, "The Attitudes towards the Jews in the Christian Polemic Literature in Poland in the 16th-18th Centuries," Jews and Slavs 11 (2003), 58-78.

7 Jan Stanisław Wujkowski, Kontrowersje polskie albo prawda otwierająca dyssydeńskie oczy do poznania prawdy prawdziwej wiary . . . z przydatkiem o niewierności i ślepocie żydowskiej (Warsaw, 1735), 270-274. 
follow." However, some Roman Catholic polemists claimed that the Orthodox priests consulted the rabbis in order to determine their date of Easter. Thus, Jan Broscyusz of Kurzelów wrote in his "First Apology of the Roman Common Calendar" published in Cracow in 1641: "There was a case with the Russian priests and their hierarchs, when they came to speak with the Jews about the Easter, as far as I understand because they believed that the Jews calculate the time of the Pascha better than the Christians."9

\section{Jews in the Inter-Confessional Christian Polemic Literature on the Union of Brześć}

Even though the Orthodox and Uniates held the same positions regarding the nature of the consecrated bread and the date of Easter, the Jews figured in a bitter polemic between these two churches for and against the Union of Brześć. As is the case with some current online debates, this polemic was conducted by parties using false identities: a Calvinist masking himself as an Orthodox, a Greek disguised as a Ruthenian. In 1597 a book entitled Apokrisis [Answer] appeared in Vilna first in Polish, and then in Ruthenian. Its author called himself Christopher Philaletes ("friend of truth" in Greek). ${ }^{10}$ This was an Orthodox answer to the book written by the famous Polish preacher, prolific writer, and a leading figure of the Polish Counter-Reformation, Jesuit Piotr Skarga (1536-1612), in favor of the Union of Brześć. ${ }^{11}$ A Uniate response had appeared already in 1599 also under a pen name of Philotheos ("friend of God" in Greek) entitled Antirrhisis [Counterresponse]. ${ }^{12}$ Its author was Peter Arkoudios, a Greek convert to Roman Catholicism from Island of Corfu, who became a Jesuit. Since he knew neither Polish nor Ruthenian, he wrote this tractate

${ }^{8}$ Peter L'Huillier, The Church of the Ancient Councils: The Disciplinary Work of the First Four Ecumenical Councils (Crestwood, 1996), 25. All translations of the quotes in this paper are mine - J. K.

${ }^{9}$ Jan Broscyusz, Apologia pierwsza Kalendarza Rzymskiego powszechnego (Kraków, 1641).

${ }_{10}$ Христофор Филалет, “Апокрисис," in Памятники полемической литературы в Западной Руси, vol. 2: 1003-1820.

11 Петр Скарга, “Берестийский собор и оборона его," in Памятники полемической литературьв в Западной Руси, vol. 2: 939-1002.

12 Филофей, “Антиризис или Апология против Христофора Филалета,” in Памятники полемической литературы в Западной Руси, vol. 3 (Петербург, 1903), 477982 (Русская историческая библиотека, издаваемая археографическою комиссиею, vol. 19). 
in Latin, and it was translated into Polish and Ruthenian by Hypaty (Poty), the future Uniate Metropolitan of Kiev. Arkoudios had already claimed that the author of Apokrisis was in fact a Calvinist pretending to be an Orthodox, but he did not disclose the name of the person he suspected of writing the book. It was only in 1781 that the Polish writer Ignacy Stebelski identified the author of Apokrisis as Christopher Bronski, a Calvinist member of a literary circle of Prince Constantine of Ostróg..$^{13}$ An alternate identification was offered by the Polish scholar Józef Tretiak, who proposed in 1912 that Marcin Broniewski, ${ }^{14}$ a Calvinist writer from Cracow ${ }^{15}$ and a secretary of the Polish King, Stefan Batory, was in fact the author.

In any case, the Protestant, especially Calvinist, influence is conspicuous in the Apokrisis. Such an unlikely Calvinist-Orthodox cooperation against the Union of Brześć became possible because of the common interest of religious minorities to preserve the famous religious tolerance of the sixteenth-century Commonwealth, which was crumbling under attacks of the Roman Catholic Counter-Reformation. Calvinist and Othrodox nobles even formed a common confederation in Vilna in 1599. This cooperation was, however, an uneasy one for both sides, and for this reason the polemists of that age decided to hide their true identities.

Jews are mentioned in Apokrisis in a context typical of the Protestant religious polemics. When speaking of the Council of Trent (1545-1563), which proclaimed the beginning of the Roman Catholic Counter-Reformation, Philaletes says: "more than one Jew is hiding behind those statutes" ("не один ся Жыд в тых ухвалах крыт"-the rhyme exists only in Ruthenian; in Polish: "niejeden się Żyd w tych uchwałach grzebie"; this puts in question the original language of this composition).${ }^{16} \mathrm{He}$ also loosely quotes the Babylonian Talmud: "Simple Jews are not allowed to argue in complicated matters with the gentiles; they can only answer 'we do not understand these matters, only our rabbis can answer you." ${ }^{17}$ The argument is purely a Protestant one, since the author opposes the idea of the intermediate position of the priest, which he attributes also to the Jews. This does not make any sense for the Orthodox polemic against the

${ }^{13}$ Ignacy Stebelski, Dwa wielkie światta na horyzoncie połockim z cieniów zakonnych powstajace (Vilna, 1781).

14 Józef Tretiak, Piotr Skarga w dziejach i literaturze unii brzeskiej (Kraków, 1912).

${ }^{15}$ On him see Janusz Byliński, Marcin Broniewski - trybun szlachty wielkopolskiej w czasach Zygmunta III (Wrocław, 1994).

16 Филалет, “Апокрисис,” 1173-1174, n. 9.

17 Ibid., 1251-1252. 
union with Rome, since the positions of the Orthodox and of the Roman Catholics in this question were identical. The attribution of this typically Protestant argument to the Orthodox became possible only in the specific circumstances of the Union of Brześć, when the majority of the Orthodox hierarchs, including all bishops and many priests, accepted the Union, while the laic Orthodox brotherhoods remained the only firm guardians of the "true faith." These brotherhoods, to a certain extent, could be presented as Orthodox correspondents to the idealized Protestant communities of believers. The use of the Talmud in Christian propaganda is no less problematic. As we have seen, Talmud remained practically unknown to the Orthodox polemists, but it was widely used by Roman Catholics and even more so by Protestant writers. The paraphrased passage is taken from the Babylonian Sanhedrin p. 38b:

-Said Rabbi Nachman: "who is able to answer to the minim [i.e. Christians] as Rabbi Idit, let him answer, but who is not, let him not answer."

The passage about the angel Metatron follows in the Talmudic text as an example of such a difficult question that ought not to be debated with the Christians by simple Jews. Metatron is often presented in the Jewish-Christian polemic as a Jewish parallel to the figure of God the Son-one of the components of the Christian Holy Trinity. This was, in fact, precisely the reason why this Talmudic passage was translated into Latin in the so-called "Paris files"- a collection of Talmudic passages translated for the Paris trial of Talmud in 1242 when the Talmud was accused of anti-Christian blasphemy, and relevant Talmudic passages were translated into Latin for presentation to the judges. ${ }^{18}$ This translation was used also by Raymond Martin in his Pugio Fidei ["Dagger of Faith"], from which it found its way to numerous polemical compositions, including our Apokrisis. However, "Dagger of Faith" remained unknown in the Orthodox East, and no quotation from it is attested in any Orthodox polemic composition.

Jews are mentioned also in the Antirrhisis surprisingly (if its author was indeed a foreigner) in a typically Polish context. According to this tractate, the Orthodox claimed that the Roman Catholic priests served as agents of Polish landlords in Ruthenian villages, just as the Jews did.

${ }^{18}$ On this translation see Gilbert Dahan, "Les traductions latines de Thibaud de Sézanne," in id. (ed.), Le brûlement du Talmud à Paris, 1242-1244 (Paris, 1999), 95-120. 
The author refutes this claim, confirming that the Jews really serve in this capacity, but that Catholic priests did not. ${ }^{19}$ The argument reflects, of course, the realities of the Polish colonization of Ukraine, where Jewish leaseholders of Polish magnates often served as the sole representatives of the landlord in a village. Their alleged equation with the Catholic priests is an interesting one: it probably means that the Polish priests were seen in the eyes of Ukrainian peasants as spiritual heralds of the expansion of the Polish folwark system and the peasants' enserfment. Protestant writers made similar claims: the Polish Calvinist poet Mikołaj Rej (1505-1569), one of the founders of Polish literature, wrote in his poem Zwierciadto [Mirror] that red-cheeked, fat Roman Catholic monks are more similar to the Jews than to "our brothers with swollen eyes and pale faces." ${ }^{20}$ This alleged cooperation between Poles and Jews was explored in yet another Uniate pamphlet, "The Ruthenian, or a Report of a Conversation of Two Ruthenians, the Schismatic with the Uniate," published by Kasper T. Skupieński in $1634 .{ }^{21}$ The "Schismatic" claims there that the Poles allowed Tatars, Armenians, and Jews to build freely their mosques, churches, and synagogues, but prohibited the building of Greek-Orthodox churches. The "Uniate" answers that the Jews had privileges which should be honored, and that they built the synagogues at their own expense, but the "Schismatics" were trying to take control of the Uniate churches.

Another matter of controversy between the Orthodox and the Uniates that involved the Jews was the Orthodox claim that the pope is the Antichrist. The concluding chapter of the Act of the Union is dedicated to this idea. ${ }^{22}$ The Uniates used a simple syllogism: if the Antichrist is the Messiah expected by the Jews, and the Jews do not believe that the pope is their Messiah, the pope cannot possibly be the Antichrist:

Also there is a true sign of the coming of the Antichrist, that the Jews will accept the Antichrist as their Messiah ... And thus if the Jews have to accept this true Antichrist as Messiah, show me any pope whom the Jews accepted as their

19 Филофей, “Антиризис,” 685-686, n. 11.

${ }^{20}$ Mikołaj Rej, Źwierciadto albo Kstalt, w którym każdy stan snadnie się może swym sprawam jako we źwierciedle przypatrzyć (Kraków, 1568).

${ }^{21}$ Kasper T. Skupieński, Rusin albo Relatia rozmowy dwóch Rusinow, Schismatyka z Unitem, o rozmnożeniu wiary Katholickiej, o Patryarchacie Cargrodzkim, o Schizmatach, o Soborach, o Uniey y chrzcie Rusi, o wolnościach Duchowieństwa Ruskiego y insze miscellanea (Warsaw, 1634).

22 “Уния греков с костелом римским," 145-168, n. 4. 
Messiah? ... Then it is true also that this Antichrist should be born from the Jewish people, as St. Jerome clearly writes. Since the Jews, who always believed and claim still now that the Messiah will come from their people, they would never accept an alien as their Messiah. . . But this is true that no pope ever was born from the Jews. ${ }^{23}$

And indeed, several decades later, as if in a fulfillment of the Uniates' prophecy, a contender for the title of the Jewish Messiah did in fact appear in a person of Sabbatai Zevi. The special place of the Jewish Messiah in the Orthodox-Uniate polemic was probably the main reason the Orthodox interest in such an internal Jewish matter as the Sabbatian movement. In 1669, only three years after the conversion of Sabbatai Zevi to Islam, Joanicyusz Gałatowski published in Kiev in the Ruthenian language a book dedicated to anti-Jewish religious polemic. ${ }^{24}$ This was one of the rare examples of the Orthodox compositions of this kind. Though written under strong Roman Catholic influence, Gałatowski's book stands in a sharp contrast to a total lack of interest in the Sabbatian movement displayed by contemporary Roman Catholic and Uniate writers. His interest in this affair was probably triggered by the need to prove that the Jews themselves rejected Sabbatai Zevi as Messiah. The conversion of Sabbatai Zevi to Islam was of great interest for Gałatowski, who in 1683 published a second book dedicated to the anti-Islamic polemic, ${ }^{25}$ where he claimed that the mother of Muhammad was Jewish, and this explains the Jewish influence on Islam. The Roman Catholic or Uniate response to Gałatowski's book appeared in an anonymous pamphlet "Epistle to Galatians," ${ }^{\text {"26 }}$ whose author wrote mockingly that as a result of Jewish rumors about miracles of the false Messiah, some Christians began to panic and prove to themselves that Jesus Christ was indeed the true Messiah. One of them, namely Gałatowski, went so far as to travel through Russian and Lithuanian lands in order to collect material to that effect among the Jews, and lately published a book entirely based upon his conversations with the Jews.

${ }^{23}$ Ibid., 159-160.

${ }^{24}$ Иоанникий Галятовский, Мессия правдывый Исус Хрыстос, Сын Божый од початку свита через вси вики людям от Бога обищаны (Киев, 1669).

${ }_{25}$ Иоанникий Галятовский, Алкоран Магометов от Когелета Христова разрушенный и ни во что обращенный (Чернигов, 1683).

${ }^{26}$ List do Galatów. See Michał Wiszniewski, Historya literatury polskiej (Kraków, 1851), 8: 394-395. 


\section{"There Are in Poland Old and New Jews": Jews against Arians}

The Orthodox-Protestant cooperation against the Union of Brześć was an exceptional phenomenon. Normally, Roman Catholic, Uniate and Orthodox polemists held practically identical position in their anti-Protestant polemic. The pioneer of the Orthodox anti-Protestant polemic was Artemy the Elder (Старец Артемий) - a rather picturesque figure of Muscovite origin. In 1554, he was accused of some heresy, condemned by the One-Hundred Chapters Council (Стоглавый Собор), and impaled in the infamous Solovki monastery on a frozen island in the White Sea. Artemy fled from there, and after many adventures reached the Grand Duchy of Lithuania, where he settled in Słuck, as did many other political refugees from Muscovy. There Artemy wrote several epistles, mainly directed against Protestants. Some of them were part of his correspondence with the "Arian" poet Szymon Budny (1530-1593), the translator of the Bible into Polish, who also resided in Słuck at that time. Like other anti-Protestant polemists, Artemy accused the Protestants of being similar to the Jews in several ways: their preference of the Decalogue over the Gospels, their iconoclastic views, and their free interpretation of the Scripture. With regard to this last point, Artemy accused Jan Hus and his followers of holding Judaizing opinions. ${ }^{27}$ It is not clear whether this reference to the extinct movement echoed the so-called "Judaizers" controversy in Muscovy, or it possibly reflected the fact that some Bohemian Brethren-spiritual remnants of the Hussite movement-found refuge in the eastern parts of the Polish-Lithuanian Commonwealth. ${ }^{28}$ Artemy called the "Arians" "uncircumcised Jews," ${ }^{29}$ and this radical anti-Trinitarian sect, called, in fact, Socinians or Unitarians ("Arians" was a derogatory nickname used by their opponents) because of their denial of the Holy Trinity, served also as a favorite target of accusations of Judaizing by Roman Catholics. Thus, an Italian Jesuit in Kalisz, Alfonso Pisani, called

27 Артемий Старец, “Послание Симону Будному,” in Памятники полемической литературы в Западной Руси, vol. 1 (Петербург, 1878), 1318 (Русская историческая библиотека, издаваемая археографическою комиссиею, vol. 4).

${ }^{28}$ See Haim Hillel Ben-Sasson, "Jews and Christian Sectarians: Existential Similarity and Dialectical Tensions in Sixteenth-Century Moravia and Poland-Lithuania," Viator 4 (1973), 369-386.

29 Артемий Старец, “Послание Ивану Зарецкому,” in Памятники полемической литературы в Западной Руси, vol. 1: 1280. 
them in 1587 simply "new Jews." He also used the same expression as the Orthodox Artemy_- "uncircumcised Jews" (Sunt in Polonia veteres et novi Judei. Sunt enim quidam Judei sine circumcisione- "There are in Poland old and new Jews. Some of them are the uncircumcised Jews"), referring to the same Szymon Budny and his friends..$^{30}$ Another Jesuit, Mikołaj Cichowski, also frequently mentions Jews in his numerous polemical compositions against Arians. Entire chapters are dedicated to the Jews, where their errors are presented as having been previously disproved by Roman Catholics, but repeated now by the Arians. ${ }^{31}$ Cichowski quotes Jesuit preachers Jan Górski and Piotr Skarga, ${ }^{32}$ who were first to claim that the Arians are more like the Jews than the Roman Catholics. He adds that it is not surprising that the Jews and the Turks spit upon the Christian faith and mock it, since they see how other Christians teach, for example, that the Holy Spirit, which appeared in a form of a dove, was, in fact, a light and shadow illusion. He continues that many Jews converted to Christianity, and therefore there are so few Jews, but the Christians have drawn closer to Judaism via Arianism. Arians themselves, according to Cichowski, admit that many of them finally converted to Judaism, which highlights how similar Arianism is to Judaism. They also prefer the company of the Jews to that of other Christians, and their ministers of religion are more similar to Talmudic sages than to Christian priests. He also claims that no Jew ever dared to write a book showing the error of Christianity, a fact that proves the inferiority of the Jewish faith. However, he states, there was one Jew, Jacob of Bełżyce, who wrote that the Arians are so similar to the Jews that they should circumcise their children and observe the Shabbat. This Jew wrote his book as a response to the collection of dialogues by Czechowicz the Arian. Cichowski continues that Czechowicz answered to this criticism, but he did this so unconvincingly that, if Cichowski were a Jew, he would win in this dispute easily. ${ }^{33}$

Marcin Czechowicz, whom Cichowski mentions, was a leading Arian polemist. He claimed in one of his compositions, published in 1581, that was written as a response to a Jew called Jacob of Bełżyce, who had written

${ }^{30}$ Michał Wiszniewski, Historya literatury polskiej (Warsaw, 1857), 9: 91.

${ }_{31}$ Mikołaj Cichowski, Trzydzieści przyczyn, dla ktorych każdy zbawienia dusznego y poczćiwości swoiey szanuiacy, ma się odrażać od Żboru tego, który Arriańskim zowia (Kraków, 1652), 171-179.

${ }^{32}$ Piotr Skarga, Żywoty świętych Starego i Nowego Zakonu na każdy dzień przez cały rok (Warsaw, 1933).

${ }^{33}$ Cichowski, Trzydzieści przyczyn, 178, n. 28. 
a polemical tractate directed against an earlier composition by Czechowicz published in 1575. Ciechowski's reference to this Jacob of Bełżyce is very important, since the very existence of this person is uncertain. His composition has never been found, and, according to Weintraub, he was never mentioned by anyone other than Czechowicz. Weintraub claims that Czechowicz invented this Jewish polemist for the purpose of his own polemic against the Roman Catholics in order to disprove their claim of the similarity between the Arians and the Jews. ${ }^{34}$ However, as we have seen, Jacob of Bełżyce, contrary to Weintraub's claim, is mentioned by another Polish writer, though it is possible that he was known to Cichowski only through Czechowicz. In any case, it seems that both the Arians and the Jews refuted the Roman Catholic and Orthodox claims regarding the similarity between Arianism and Judaism.

On the Jewish side, the Karaite polemist, Isaac of Troki, presents Szymon Budny favorably in his book Hizuk emunah - the only anti-Christian polemical composition from the Jewish perspective ever written in the Polish-Lithuanian Commonwealth. ${ }^{35}$

\section{Roman Catholic and Orthodox Anti-Protestant Views on the Jewish Kabbalah}

Roman Catholic and Orthodox anti-Protestant polemics differed in one regard: their attitude toward the Jewish Kabbalah. The Orthodox Afanasy Philipovich wrote in his Diary in 1646 that he had seen in Cracow and Raków many Jewish kabbalistic books (чорнокнижские), which should be forbidden in a Christian country. ${ }^{36}$ His reference to Raków is of particular interest, since this was the location of an Arian theological academy known as "Sarmatian Athens." This academy was founded in 1602 and continued to function there until the expulsion of Arians from Poland in 1658. The matter is that in the seventeenth century the Protestants held positive views about the Jewish Kabbalah, seeing it as a link between

${ }^{34}$ Wiktor Weintraub, "Tolerance and Intolerance in Old Poland," Canadian Slavonic Papers 12 (1971), 30-31.

${ }^{35}$ On the Jewish attitudes towards Protestantism see Haim Hillel Ben-Sasson, "The Reformation in Contemporary Jewish Eyes," Proceedings of the Israel Academy of Sciences and Humanities 4 (1971), 12: 239-326.

36 Афанасий Филиппович, “Диариуш," in Памятники полемической литературы в Западной Руси, vol. 1: 134. 
Judaism and Christianity. ${ }^{37}$ The early Silesian Pietist, Christian Knorr von Rosenroth, translated a large part of the book of Zohar into Latin under the name Kabbala Denudata [Unveiled Kabbalah] in the last quarter of the seventeenth century for the express purpose of using it as a tool for converting Jews to Christianity. ${ }^{38}$ This work served as a scholarly basis for the massive use of the Kabbalah in missionary activities among the Jews in Germany and later in Poland. Roman Catholics, in contrast to the Orthodox, shared this view on the Jewish Kabbalah as a link between Judaism and Christianity with Protestants. The Roman Catholic Pietro Colonna Galatino expressed this view as early as 1516 in his book written at the request of Pope Leo X. ${ }^{39}$ In Poland, however, the interest of the Roman Catholic clergy in the Kabbalah was triggered by the German Pietist mission among Polish Jews. ${ }^{40}$ Only in the eighteenth century such Polish preachers as Franciszek Antoni Kobielski ${ }^{41}$ and Jan Poszakowski ${ }^{42}$ began to use the book of Zohar and some other compositions of the socalled "Lurianic Kabbalah" (such as Pardes rimonim by Moses Cordovero and Avodat ha-kodesh by Meir Gabbai) in their sermons in synagogues.

\section{Conclusions}

To sum up: Jews are often mentioned in Christian polemic literature not in the context of Adversus Judaeos tradition, but as an example for comparison in the context of religious polemics of various Christian denominations against each other. It is interesting that different Christian factions entered in the course of this polemic into rather unexpected alliances concerning this or that aspect of Judaism: the Uniates and the Orthodox held the same position in matters of the nature of consecrated bread and the Easter calculation, Orthodox cooperated with the Protestants against the Union

${ }^{37}$ On this subject see Judith Kalik, "Christian Kabbala and Polish Jews: Attitudes of the Church to Jewish Conversion and the Idea of 'Jacob's Return' in the Polish-Lithuanian Commonwealth in the 18th Century," Jewish History Quarterly 212 (2004), 492-501.

${ }^{38}$ Christian Knorr von Rosenroth, Kabbala Denudata, vol. 1-2 (Sultzbach, 1677-1684).

${ }_{39}$ Pietro Colonna Galatino, De arcanis Catholicae veritas (Roma, 1516).

${ }^{40}$ See: $W$ poszukiwaniu żydowskich kryptochrześcijan. Dzienniki ewangelickich misjonarzy z ich wędrówek po Rzeczypospolitej w latach 1730-1747, ed. Jan Doktór (Warsaw, 1999).

${ }^{41}$ Franciszek Antoni Kobielski, Światto na oświecenie narodu niewiernego, to iest kazania $w$ synagogach żydowskich miane, oraz reflexye y list odpowiadaiacy na pytania Synagogi Brodzkiey (Lwów, 1746).

42 Jan Poszakowski, Zohar co znaczy splendor, jasność, swiattość z okazyi starego zydowskiego Zoharu... (Warsaw, 1749). 
of Brześć, Catholics and Uniates were united against the Orthodox claim that the pope was the Antichrist, Catholics and Orthodox alike equated Arians with the Jews, but Catholics and Protestants saw the Jewish Kabbalah in a positive way, while the Orthodox held the negative view. Jews, on their part, mostly ignored this kind of polemic, except for an attempt to distance themselves from the equation with the Arians, on the one hand, and the use of Arian arguments in their polemic against the Catholics for the criticism of Christianity in general, on the other hand.

Judith Kalik

The Hebrew University of Jerusalem kalik@012.net.il 